Brazilian Journal

of Chemical

Engineering

\title{
BIODIESEL SYNTHESIS FROM WASTE COOKING OIL USING A VARIETY OF WASTE MARBLE AS HETEROGENEOUS CATALYSTS
}

\author{
Abdul Majeed Khan ${ }^{1 *}$, Abdul Hadi Safi ${ }^{1}$, Muhammad Naeem Ahmed ${ }^{2}$, \\ Ali Raza Siddiqui ${ }^{1}$, Muhammad Arsalan Usmani ${ }^{1}$, \\ Saad-ul-Haq Khan ${ }^{1}$ and Kousar Yasmeen ${ }^{1}$ \\ ${ }^{1}$ Federal Urdu University of Arts, Science and Technology, Department of Chemistry, Research Laboratory of Bioenergy, Karachi, \\ Pakistan. E-mail: dr.abdulmajeedkhan@fuuast.edu.pk - ORCID: 0000-0002-2731-9818; ORCID: 0000-0002-9495-191X; \\ ORCID: 0000-0002-7563-2585; ORCID: 0000-0003-2942-4387; ORCID: 0000-0003-2828-3842; ORCID: 0000-0003-0481-6747 \\ ${ }^{2}$ The University of Azad Jammu and Kashmir, Department of Chemistry, Muzaffarabad, Pakistan. ORCID: 0000-0002-5559-1763
}

(Submitted: January 16, 2019 ; Revised: March 14, 2019 ; Accepted: April 13, 2019)

\begin{abstract}
The research article is based on biodiesel synthesis by the transesterification of waste cooking oil with methanol in the presence of heterogeneous catalysts prepared from different marble. Eight samples of marble were successfully converted into potential catalysts by calcination. The thermal treatment of waste marbles at $300^{\circ} \mathrm{C}-1000^{\circ} \mathrm{C}$ converted the metal carbonates $\left(\mathrm{CaCO}_{3}\right)$ to metal oxides $(\mathrm{CaO})$. The calcined marble was analyzed by chemical tests, flame atomic absorption spectroscopy (FAAS), Fourier transform infrared spectroscopy (FTIR), and X-ray diffraction studies (XRD). The presence of $\mathrm{CaO}$ in these catalysts made them highly reactive for biodiesel synthesis. The basicity and percentage of calcium in marble catalysts were calculated to know their basic strength. The transesterification was performed by fast stirring using waste cooking oil, methanol and nine different types of marble catalysts for $5 \mathrm{~min}$ at five different conditions, i.e., room temperature, hot plate stirring, solar ordinary irradiations, solar concentrated reflected irradiations and solar concentrated refracted irradiations. The solid catalysts were easily separated from the product for re-use. All marble catalysts were found to be active and basic except one namely silver pun (I). The production of biodiesel was confirmed by ASTM standards, TLC examination and by gas chromatography (GC).

Keywords: Waste cooking oil; Waste marble; Heterogeneous catalyst; Transesterification; Biodiesel.
\end{abstract}

\section{INTRODUCTION}

The global society is worried about the energy crisis because of the limited availability of fossil fuels and environmental problems, mainly the increasing trend of global warming due to the emission of $\mathrm{SO}_{x}$ and $\mathrm{CO}_{2}$ from the combustion of fossil fuels (Nisar et al., 2017; Khan \& Hussain, 2017). Because of environmental problems and fossil fuel depletion, the search for an alternative fuel has increased. One of the alternative energy sources among hydrogen, solar energy, wind energy etc. is biodiesel. Biodiesel is produced from renewable sources such as animal fats, vegetable oil, macro algae and microalgae. Biodiesel is fatty acid alkyl esters produced by the transesterification reaction from animal fats or vegetable oil. However, biodiesel production from edible animal fats and vegetable oil causes two main problems. One they are competitive with food and second their high price causes a high cost of biodiesel. Therefore, the most relevant and suitable renewable source for biodiesel production is waste cooking oil (WCO). It can be collected from household kitchens and restaurants at low price and hence can reduce the cost of biodiesel production (Maneerung et al., 2016; Khan et al., 2017; Khan \& Fatima, 2015). Large quantities of WCO oil are produced all over the

\footnotetext{
*Corresponding author: Abdul Majeed Khan - E-mail: dr.abdulmajeedkhan@fuuast.edu.pk
} 
world. Some fraction of the WCO oil has been used in preparation of soap but most of its quantity is dumped into landfills and rivers, causing land pollution and water pollution (Mahesh et al., 2015). Vegetable oil has been converted into biodiesel usually through conventional heating. Some other processes have been used for biodiesel production such as sonication, solar irradiation and microwave assisted transesterification. These have been used to intensify the reaction and to increase the biodiesel product in short time. Sonication speeds up the reaction through ultrasonic irradiation and enhances the biodiesel product, while in microwave assisted transesterification, the reaction mixture is irradiated with microwaves (Gude and Grant, 2013; Azcan and Danisman, 2008).

The main factor in biodiesel synthesis is the selection of the catalyst. Various catalysts, including homogeneous catalysts, heterogeneous acidic and basic catalysts and enzymes (Vahid \& Haghighi, 2017; Khan \& Fatima, 2016; Charpe \& Rathod, 2011), have been reported for biodiesel production. Among homogeneous catalysts $\mathrm{NaOH}, \mathrm{KOH}$ and $\mathrm{CH}_{3} \mathrm{ONa}$ catalysts have been reported for transesterification. These catalysts are cheap and easily available but they have some drawbacks; these catalysts may cause saponification, which reduces yield of product, secondly they cause difficulty in separation of the glycerol and biodiesel layers. Acid homogeneous catalysts such as $\mathrm{HCl}$ and $\mathrm{H}_{2} \mathrm{SO}_{4}$ are free of such drawbacks but their reaction rate is slow (TalebianKiakalaieh et al., 2013). All homogeneous catalysts (acid or base) are separated at the end of reaction by washing, which causes the reduction of product yield. Furthermore, such catalysts cause reactor corrosion and are difficult to recover. These problems can be overcome by replacing homogeneous catalysts with heterogeneous catalysts. Heterogeneous catalysts can be recovered at the end of reaction easily without the loss of catalytic activity and hence can be used repeatedly (Farooq \& Ramli, 2015; Khan et al., 2016). Heterogeneous catalysts are non-corrosive and good for environment. Various heterogeneous catalysts such as oxides, mixed oxides, phosphates, sulphates and chlorides etc have been reported for transesterification (Khan \& Fatima, 2016; Pukale et al., 2015). Heterogeneous catalysts reduce the purification process and hence result in the less consumption of energy. Heterogeneous catalysts are cost effective because they can be obtained from waste sources like bones, ashes, shells and rocks (Tan et al., 2015). A number of research articles have been published using calcium oxide $(\mathrm{CaO})$ as a heterogeneous catalyst. $\mathrm{CaO}$ can be obtained from various waste sources such as bones, egg shells, scales, corals, calcite containing rocks and marble through the process of calcination (Bennett et al., 2016). In this research work waste marble has been used as a source of $\mathrm{CaO}$, which is an effective catalyst for transesterification reaction.
Huge amounts of waste marble have been generated on construction sites and from marble cutting industries, which are used as landfill. The catalytic effect of waste marble for transesterification of WCO has not been investigated much until now (Balakrishnan et al., 2013). Transesterification of canola oil with methanol using marble dust as catalyst has been reported. Marble dust generated during the cutting process of marble affects health and causes environmental pollution (Ilgen, 2012). Waste marble has been also used as catalyst in transesterification of jatropha oil. The catalytic activity of $\mathrm{CaO}$ has been enhanced with barium metal (Olutoye, 2015). In this research work a detailed comparative study of nine different marbles is given, whereas in the literature an extensive comparison is not provided; therefore, it is a new contribution in this regard.

The approach of this research work is more significant because all the raw materials for biodiesel production are cost effective. The WCO can be collected at very low price and the waste marble used as a source of catalyst has almost no cost, although both have some processing cost. The biodiesel produced through this research work has comparatively less production cost. This work is new because it provided the detailed comparative study of nine different marbles. Their characterization with powerful tools including FAAS, FTIR and XRD was conducted, which is also a new addition in heterogeneous catalysis for biodiesel synthesis. This research work introduces a new approach using satellite dish and Fresnel lens, which intensified the solar radiation for the transformation of the conventional heat based reaction to the solar irradiation.

\section{EXPERIMENTAL}

\section{Materials}

Waste cooking oil was collected from local restaurants and different marble samples having the brand names China Verona marble (A), Ziarat White marble (B), Karara white marble (C), Dinocite marble (D), Chocolate-1 marble (E), Chocolate-2 marble $(\mathrm{F})$, Botiseena marble $(\mathrm{G})$, Afghani marble $(\mathrm{H})$ and Silver Pun marble (I) were collected from the Korangi industrial area, Karachi, Pakistan (Figure 1). The methanol used was of analytical grade.

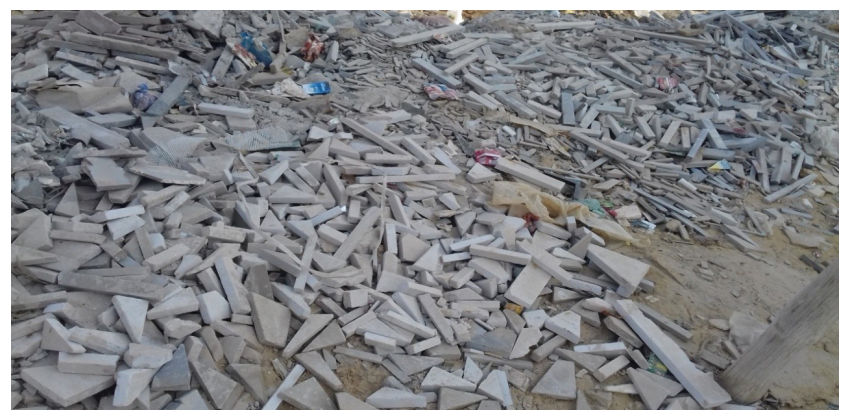

Figure 1. Marble collection site. 


\section{Preparation of catalysts}

Waste pieces of marble of nine different types (A to I) were collected from the Korangi industrial area, Karachi, Pakistan. The waste marble pieces were ground using a mortar and pestle. The ground marble samples were calcined in a furnace (made in China) at $300^{\circ} \mathrm{C}$ to $1000^{\circ} \mathrm{C}$ for different intervals so that the calcium carbonate was converted into calcium oxide. The silver pun marble (I) was melted at $700^{\circ} \mathrm{C}$. The calcined marbles were filtered through a small pore size cloth to get the refined powder (Figure 2a and $2 b$ ). The refined marbles powder was characterized by different techniques such as basicity test, gravimetric analysis, qualitative analysis, FAAS, FT-IR and XRD.

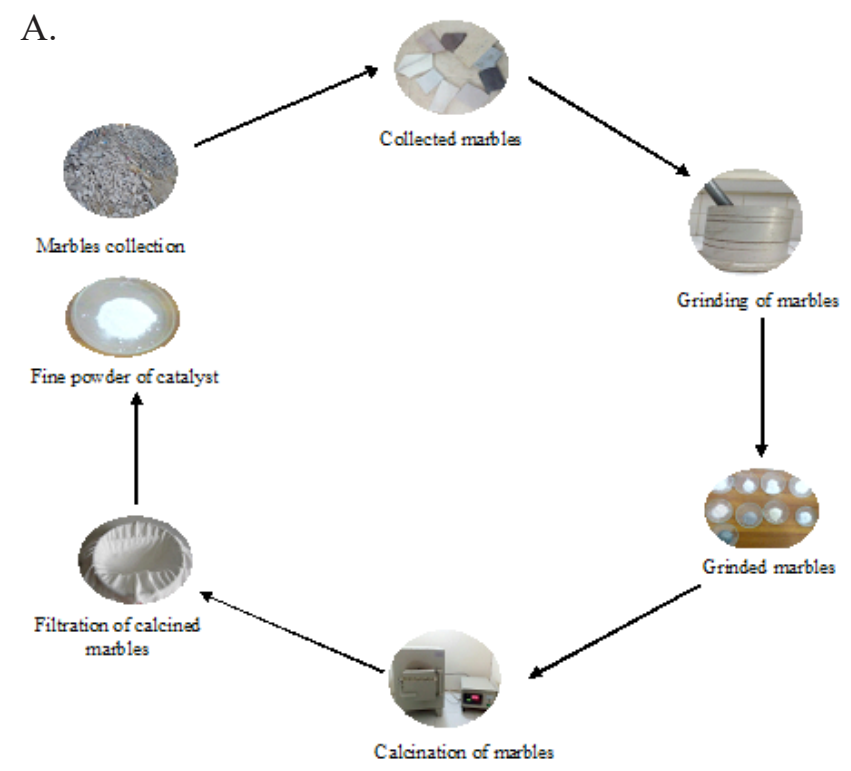

B.

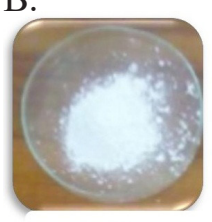

A

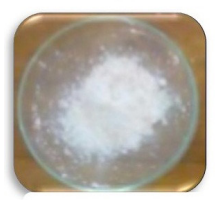

E

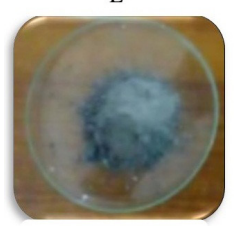

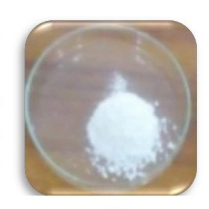

B

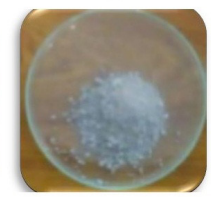

F

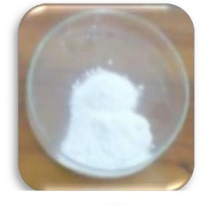

C

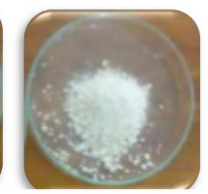

G

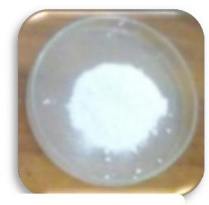

D

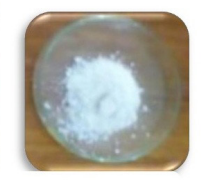

$\mathrm{H}$

Figure 2. Preparation of catalyst (a) and images of calcined marbles A to I (b).

\section{Characterization of catalysts}

The fine powders of catalysts of all samples were characterized by different techniques such as basicity

test, gravimetric analysis, qualitative analysis, flame atomic absorption spectroscopy (PE-A Analyst 700 having wavelength range $200-800 \mathrm{~nm}$, flame type Air$\mathrm{C} \mathrm{H}$ and fuel flow $10 \mathrm{~L} / \mathrm{min}$ ), Fourier transform infrared spectroscopy (Nicolet FTIR 5DX spectrometer using the $\mathrm{KBr}$ technique) and XRD (Bruker D8-Advance diffractometer).

\section{Basicity of catalysts}

Basicity of the catalysts was determined by using the method of Frailer 2010. A $20 \% \mathrm{w} / \mathrm{v}$ solution of each catalyst (A to I) was prepared. Benzoic acid solution in toluene $(0.01 \mathrm{M})$ was prepared. Phenolphthalein indicator was prepared in toluene $(1.5 \mathrm{mg} / \mathrm{mL})$. Solutions of each catalyst $(1 \mathrm{~mL})$ and phenolphthalein $(0.5 \mathrm{ml})$ were placed in a conical flask and benzoic acid solution in the burette. The solution of each catalyst was titrated against benzoic acid. The volume of benzoic acid solution consumed was noted and the basicity of the catalyst determined as mill moles of benzoic acid per $100 \mathrm{~g}$ of catalyst. On the other hand, a saturated solution of each catalyst was prepared and their $\mathrm{pH}$ was noted using a $\mathrm{pH}$ meter (JENWAY-3510 $\mathrm{pH}$ meter).

\section{Gravimetric analysis}

Catalyst $(0.2 \mathrm{~g})$ was mixed with distilled water $(12.5 \mathrm{ml})$ and conc. $\mathrm{HCl}(4.0 \mathrm{~mL})$ was added. The mixture was stirred, covered and boiled. Then the solution was prepared by the addition of distilled water (125 mL). Methyl red (2 drops) was also added, the solution was covered and boiled. In another beaker, a solution of ammonium oxalate $(8 \% \mathrm{w} / \mathrm{v})$ was prepared and boiled. The solution of ammonium oxalate and $\mathrm{NH}_{4} \mathrm{OH}$ was added to the sample solution dropwise until orange precipitate appeared. The solution was filtered and the residue collected. The residue was charred at $1000^{\circ} \mathrm{C}$ and weighed for the $\mathrm{CaO}$ content. The process was repeated for all catalysts.

\section{Qualitative analysis}

Qualitative tests were performed on non-calcined and calcined samples of marble. Qualitative tests were limited to the detection of calcium and carbonate. To detect carbonate, diluted $\mathrm{HCl}$ was added to both noncalcined and calcined marbles and the solution heated. For the detection of calcium, an original solution of both non-calcined and calcined marbles was prepared. A few drops of $\mathrm{NH}_{4} \mathrm{OH}$ and ammonium oxalate were added to original solution. The same procedure was followed for all the nine types of non-calcined and calcined marble.

\section{Flame atomic absorption spectroscopy (FAAS)}

Nine different samples of marble (A to I) were collected from the Korangi industrial area Karachi, 
Pakistan. Each sample (15 g) was weighed on an electronic balance having accuracy of $0.001 \mathrm{~g}(\mathrm{~A} \times 200$ Shimadzu, Tokyo, Japan). Samples were dried in a furnace at $700 \pm 5^{\circ} \mathrm{C}$ for $6 \pm 1$ hours to remove moisture; dried samples were further blended using a blender (National NG-786, 2004TG). Dried and blended samples were further powdered by crushing with a pestle and mortar. Powdered sample $(15 \pm 0.01 \mathrm{~g})$ was taken up in $\mathrm{HNO}_{3}(5 \mathrm{~mL})$ and refluxed overnight. The refluxed samples were digested on a hot stirrer plate at $80{ }^{\circ} \mathrm{C}$ until a honey white yellow clear solution was obtained then 1-2 $\mathrm{ml}$ of $\mathrm{HClO}_{4}$ was added in solution and digested again until homogeneous and clear solution obtained. The resulting solution was filtered through Whatman No.42 filter paper and further diluted to $50 \mathrm{~mL}$ using de-ionized water. The resulting solutions were used for the detection of $\mathrm{Ca}, \mathrm{Cd}, \mathrm{Cu}$, $\mathrm{Fe}, \mathrm{Ni}, \mathrm{Mg}, \mathrm{K}, \mathrm{Na}, \mathrm{Pb}$ and $\mathrm{Zn}$ by using an Atomic Absorption Spectrometer (Perkin-Elmer, Model: AAnalyst-700).

To run samples; a series of standard solutions of metals having different concentrations were run and marble sample concentrations were determined by regression analysis. Each sample was analyzed in triplicate and the mean concentration of each sample was reported in $\mathrm{mg} \mathrm{kg}^{-1}$ (ppm). The measurements were made using a hollow cathode lamp of $\mathrm{Ca}, \mathrm{Cd}$, $\mathrm{Cu}, \mathrm{Fe}, \mathrm{Ni}, \mathrm{Mg}, \mathrm{K}, \mathrm{Na}, \mathrm{Pb}$ and $\mathrm{Zn}$ at wavelengths (nm) of $422.7,228.8,324.8,248.3,232.0,285.2,766.5$, $589.0,283.3$ and 213.9 respectively. The slit width was adjusted for all the metals at $0.7 \mathrm{~nm}$ (Table 1 ).

Table 1. Parameters used for metal analysis by flame atomic absorption spectrophotometer (FAAS) PEAAnalyst 700.

\begin{tabular}{ccccc}
\hline Metal & $\begin{array}{c}\text { Wavelength } \\
\text { (nm) }\end{array}$ & Replicates & $\begin{array}{c}\text { Fuel flow } \\
\text { (L/min) }\end{array}$ & $\begin{array}{c}\text { Flame } \\
\text { type }\end{array}$ \\
\hline $\mathrm{Ca}$ & 422.7 & 3 & 10 & $\mathrm{Air}-\mathrm{C}_{2} \mathrm{H}_{2}$ \\
$\mathrm{Cd}$ & 228.8 & 3 & 10 & $\mathrm{Air}-\mathrm{C}_{2} \mathrm{H}_{2}$ \\
$\mathrm{Cu}$ & 324.8 & 3 & 10 & $\mathrm{Air}-\mathrm{C}_{2} \mathrm{H}_{2}$ \\
$\mathrm{Fe}$ & 248.3 & 3 & 10 & $\mathrm{Air}-\mathrm{C}_{2} \mathrm{H}_{2}$ \\
$\mathrm{~K}$ & 766.5 & 3 & 10 & $\mathrm{Air}-\mathrm{C}_{2} \mathrm{H}_{2}$ \\
$\mathrm{Mg}$ & 285.2 & 3 & 10 & $\mathrm{Air}-\mathrm{C}_{2} \mathrm{H}_{2}$ \\
$\mathrm{Na}$ & 589.0 & 3 & 10 & $\mathrm{Air}-\mathrm{C}_{2} \mathrm{H}_{2}$ \\
$\mathrm{Ni}$ & 232.0 & 3 & 10 & $\mathrm{Air}-\mathrm{C}_{2} \mathrm{H}_{2}$ \\
$\mathrm{~Pb}$ & 283.3 & 3 & 10 & $\mathrm{Air}-\mathrm{C}_{2} \mathrm{H}_{2}$ \\
$\mathrm{Zn}$ & 213.9 & 3 & 10 & Air- $\mathrm{C}_{2} \mathrm{H}_{2}$ \\
\hline
\end{tabular}

\section{Purification of waste cooking oil}

Waste cooking oil $(250 \mathrm{~mL})$ was filtered through ordinary filter paper to separate the gummy residues and solid waste particles. After filtration, the waste cooking oil was de-acidified with $10 \% \mathrm{NaOH}$ solution. The gummy particles were settled down and were heated on water bath and filtered through Whatman filter paper. After filtration, the oil was treated with bleach $(20 \mathrm{~mL})$ for the removal of pigmentation and undesired particles. After bleaching, two layers were observed, creamy gummy particles that settled down in the lower layer while oil remained in the upper layer, which was then heated on a hot plate with constant stirring and the temperature was noted with a thermometer. After heating, a thick solution was observed, then cooled to room temperature and filtered again through Whatman filter paper. The oil was then passed through a chromatography column packed with silica gel (as stationary phase) using $n$-hexane as mobile phase (Figure3).

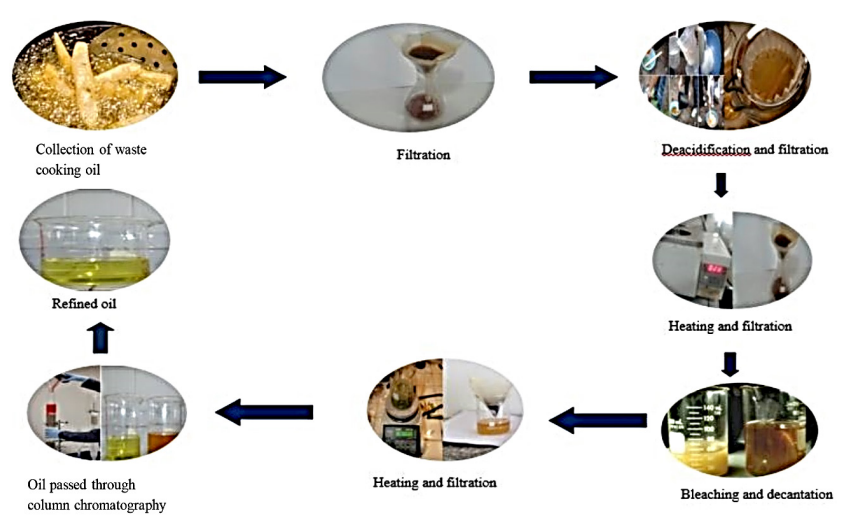

Figure 3. Experimental scheme for refining the waste cooking oil.

\section{Characterization of waste cooking oil}

Waste cooking oil was characterized by ASTM standards such as cloud point, pour point, density, viscosity and acid value (Table 5) as well as by gas chromatography (GC). Cloud point and pour point were determined by cooling the oil in a refrigerator. Density was determined by using a $20 \mathrm{~mL}$ RD bottle. The empty RD bottle was weighed and then oil was filled to the mark and again weighed; the mass was divided by the volume to give the density of oil. Viscosity was determined by using a viscometer. The acid value was determined by titrating the oil dissolved in an ethanol-toluene mixture against standardized $\mathrm{KOH}$ solution in ethanol. Phenolphthalein was used as indicator during the determination of the acid value.

\section{Transesterification}

Transesterification reactions of WCO with methanol in the presence of heterogeneous catalysts were carried out in five different conditions. Methanol to oil molar ratio (3:1 to $12: 1$ ) was investigated for optimization and all the reactions were carried out at a 12:1 molar ratio. Nine samples were prepared by taking waste cooking oil and methanol in each sample. About $0.5 \mathrm{~g}$ of each catalyst (A to I) was added separately in each sample. The reactions were carried out for 1-5 minutes at room temperature. The reaction mixtures were stirred continuously (50 $\mathrm{rpm}$ ) using a hot plate stirrer. The product mixtures so formed were separated using a separating funnel. The upper layer was separated as biodiesel (FAME) and 
the lower layer was separated as glycerol. The same procedure was repeated for conventional heating, solar ordinary irradiations, solar concentrated reflected irradiations and solar concentrated refracted irradiations (Figure 4A-C). For conventional heating, reactions
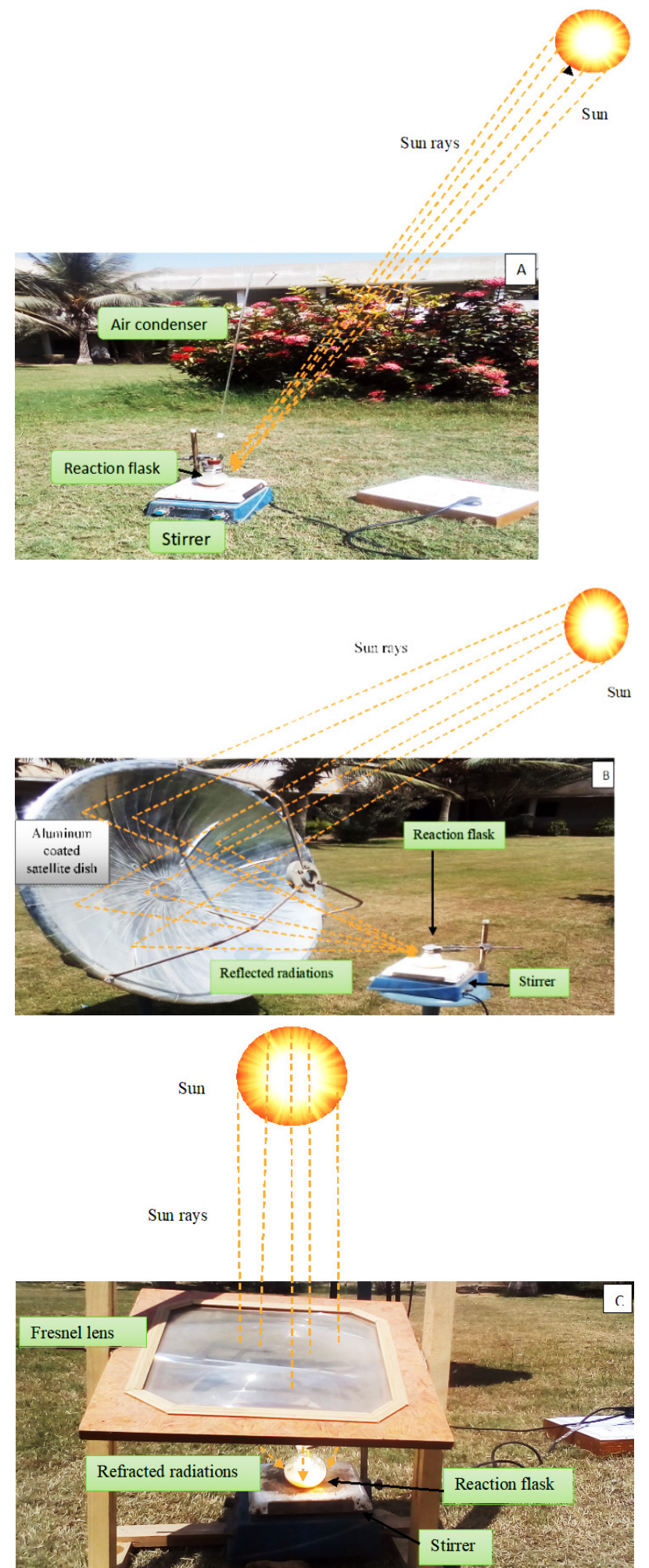

Figure 4. Transesterification under solar ordinary irradiation (A), solar concentrated reflected irradiation (B) and solar concentrated refracted irradiation (C). were conducted on a hot plate at $60^{\circ} \mathrm{C}$. The reaction flasks were fitted with a reflux condenser. For ordinary solar irradiations reaction, flasks were kept under direct sunlight. The temperature found in this condition was 45 to $50^{\circ} \mathrm{C}$. For solar concentrated reflected irradiations, the sun light was reflected and focused using an aluminum coated satellite dish and the temperature was found to be $80^{\circ} \mathrm{C}$. For solar concentrated refracted irradiations, the sunlight was refracted and focused using a Fresnel lens. The temperature in this condition was found to be 100 to $120^{\circ} \mathrm{C}$.

\section{Characterization of biodiesel}

Biodiesel so produced was characterized by ASTM standards such as cloud point, pour point, density, viscosity, acid value (Table 5), thin layer chromatography (TLC) and gas chromatography. Silica gel was used as stationary phase while an $n$-hexane : toluene : chloroform (7:2:1) mixture was used as mobile phase. The spots of biodiesel and oil were visualized using anhydrous iodine crystals (silica gel was used in the iodine tank to create an anhydrous condition) (Figure 5a-5e).

\section{RESULTS AND DISCUSSION}

Transesterification of WCO oil was carried out with methanol in the presence $\mathrm{CaO}$ as heterogeneous catalyst. $\mathrm{CaO}$ was obtained from waste marble. The main constituent of marble is $\mathrm{CaCO}_{3}$. Marble contains above $91 \% \mathrm{CaCO}_{3}$, which on calcination is converted into $\mathrm{CaO}$ releasing $\mathrm{CO}_{2}$ (Itodo et al., 2017). This $\mathrm{CaO}$ was used as an effective catalyst for biodiesel production from WCO.

\section{Characterization of catalysts}

Catalysts were characterized by basicity test, gravimetric analysis, qualitative analysis, flame atomic absorption spectroscopy (FAAS), Fourier transform infrared spectroscopy (FT-IR) and XRD. Basicity of each catalyst (A to I) was determined by titrating $20 \% \mathrm{w} / \mathrm{v}$ solution of catalyst with benzoic acid solution in toluene using phenolphthalein as indicator. Basicity was determined in milli-moles of benzoic acid per $100 \mathrm{~g}$ of catalysts. Furthermore, the saturated solutions of each catalyst were prepared and their $\mathrm{pH}$ determined. The results showed that all catalysts were strongly basic except sample (I), which was found to be neutral. The high basicity values of all the samples showed that they can be used as an effective catalyst for the transesterification reaction (Table 2).

Gravimetric analysis of all the catalysts (A to I) was also carried out and the amount of $\mathrm{CaO}$ was calculated. The maximum amount of $\mathrm{CaO}(\mathrm{mg})$ was found to be $0.200 \mathrm{mg}$ for samples $\mathrm{C}$ and $\mathrm{H}$, whereas it was found to be $0.184 \mathrm{mg}$ and $0.194 \mathrm{mg}$ for B and $\mathrm{G}$ respectively. 


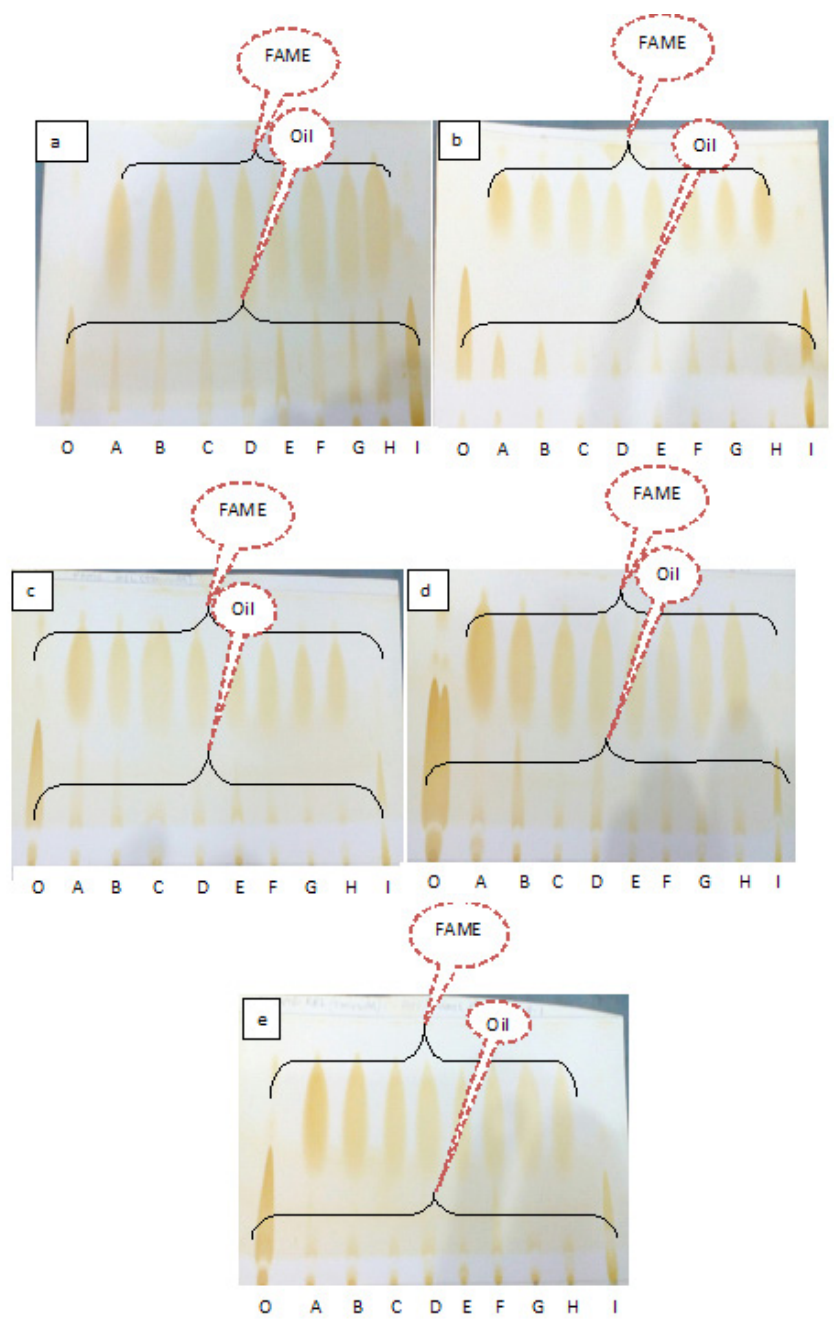

Figure 5. TLC examination of FAME produced at room temperature (a), conventional heating (b), solar ordinary irradiation (c), solar concentrated reflected irradiation (d) and solar concentrated refracted irradiation (e).

From the amount of $\mathrm{CaO}$ in each catalyst, the percentage of $\mathrm{Ca}^{++}$was calculated by the unity method (Table 2). The catalyst A was found to contain the highest percentage of $\mathrm{Ca}^{+2}(72.1 \%)$, whereas samples $\mathrm{C}$ and $\mathrm{H}$ contained $71.0 \%$ and $70.0 \%$, respectively. On the other hand, catalyst I did not contain any significant amount of $\mathrm{CaO}$.
Qualitative tests were performed for the detection of carbonate and calcium in each marble sample (A to I) for both non-calcined and calcined samples. For carbonate, when dilute $\mathrm{HCl}$ was added to the sample and the solution heated, $\mathrm{CO}_{2}$ was evolved from non-calcined samples, which showed the presence of carbonate, while no such observation was seen in calcined samples because $\mathrm{CO}_{2}$ cannot be produced from $\mathrm{CaO}$. For calcium, when $\mathrm{NH}_{4} \mathrm{OH}$ and ammonium oxalate were added to the original solution of each sample (non-calcined and calcined), white precipitates of calcium oxalate were formed in both types of samples, which showed the presence of calcium. The metal concentrations in different samples were determined by flame atomic absorption spectroscopy, which were found in the order of $\mathrm{Ca}>\mathrm{K}>\mathrm{Na}>\mathrm{Ni}>\mathrm{Mg}>\mathrm{Pb}>\mathrm{Fe}>\mathrm{Cu}>$ $\mathrm{Cd}>\mathrm{Zn}$ (Table 3). Maximum concentration of $\mathrm{Ca}$ was found in the Zairat white marble sample (22.17 mg.kg-1).

The presence of $\mathrm{CaO}$ in each calcined sample (A to $\mathrm{H}$ ) was confirmed by FT-IR spectra (Figure 6A to $6 \mathrm{H})$. The peak at $875 \mathrm{~cm}^{-1}$ shows the presence of $\mathrm{CaO}$; peaks at $1420-1500 \mathrm{~cm}^{-1}$ are due to the stretching vibration of $\mathrm{CO}_{3}^{-2}$. The appearance of a peak at $3650 \mathrm{~cm}^{-1}$ was attributed to the stretching vibration of $\mathrm{OH}$. The presence of $\mathrm{OH}$ is most likely due to the adsorption of atmospheric water on the surface of calcined samples. The results of IR spectra of $\mathrm{CaO}$ are similar to those of calcined egg shells powder and calcined C. brunneus shell (Bharathiraja et al., 2018; Mazaheri et al., 2017). Similarly, the peaks at $1420-1500 \mathrm{~cm}^{-1}$ and $3650 \mathrm{~cm}^{-1}$ for $\mathrm{CO}_{3}^{-2}$ and $\mathrm{OH}$ stretching, respectively, were also confirmed from IR spectra of calcined C. brunneus shell and calcined cement wastes (Mazaheri et al., 2017; Kumar et al., 2018).

The XRD diffraction pattern of calcined samples (A to $\mathrm{H}$ ) shows major peaks at $2 \theta$ equal to $26.771^{\circ}$, $29.780^{\circ}, 32.301^{\circ}, 35.626^{\circ}, 43.290^{\circ}, 47.404^{\circ}, 47.608^{\circ}$, $48.418^{\circ}, 54.029^{\circ}$ (Figure $7 \mathrm{~A}$ to $7 \mathrm{H}$ ). It is evident that peaks at $2 \theta$ equal to $32.38^{\circ}, 37.48^{\circ}, 53.98^{\circ}, 64.28^{\circ}$ and $67.48^{\circ}$ show $\mathrm{CaO}$ while $2 \theta=29.5^{\circ}$ shows $\mathrm{CaCO}_{3}$ (Witoon, 2011).

Table 2. Parameters of calcined marbles.

\begin{tabular}{ccccccc}
\hline S. No. & Catalysts & Basicity & $\begin{array}{c}\text { Qualitative } \\
\text { analysis } \\
\text { for Ca } \mathbf{a}^{+\mathbf{2}}\end{array}$ & $\begin{array}{c}\text { Amount of } \\
\mathbf{C a O}(\mathbf{m g})\end{array}$ & $\begin{array}{c}\mathbf{P}^{\mathbf{H}} \mathbf{\text { of }} \\
\mathbf{\text { Ca }}\end{array}$ & $\begin{array}{c}\mathbf{+ 2} \\
\text { saturated } \\
\text { solution }\end{array}$ \\
\hline 1 & China varona marble (A) & 0.045 & $\mathrm{Ca}^{+2}$ present & 0.037 & 72.1 & 12.31 \\
2 & Ziarat white marble (B) & 0.080 & $\mathrm{Ca}^{+2}$ present & 0.184 & 64.2 & 12.63 \\
3 & Karara white marble (C) & 0.055 & $\mathrm{Ca}^{+2}$ present & 0.200 & 71.0 & 12.61 \\
4 & Dinocite marble (D) & 0.045 & $\mathrm{Ca}^{+2}$ present & 0.113 & 39.9 & 11.91 \\
5 & Chocolate-1 marble (E) & 0.060 & $\mathrm{Ca}^{+2}$ present & 0.118 & 66.6 & 12.46 \\
6 & Chocolate-2 marble (F) & 0.055 & $\mathrm{Ca}^{+2}$ present & 0.163 & 55.9 & 11.83 \\
7 & Botiseena marble (G) & 0.075 & $\mathrm{Ca}^{+2}$ present & 0.194 & 69.2 & 10.82 \\
8 & Afghani marble (H) & 0.045 & $\mathrm{Ca}^{+2}$ present & 0.200 & 70.0 & 12.45 \\
9 & Silver pun marble (I) & No result & $\mathrm{Ca}^{+2}$ absent & 0.00 & 0.00 & 9.35 \\
\hline
\end{tabular}


Table 3. Determination of metal content (ppm) in marble samples by Flame Atomic Absorption Spectrophotometry (FAAS).

\begin{tabular}{lccccc}
\hline \multirow{2}{*}{ Sample ID } & Ca & Cd & Cu & Fe & K \\
\cline { 2 - 6 } & & & Mean \pm SD & & BDL \\
\hline China verona (A) & $20.39 \pm 0.092$ & BDL & $0.096 \pm 0.3438$ & BDL & $16.83 \pm 1.068$ \\
Ziarat white (B) & $22.17 \pm 0.258$ & $0.008 \pm 0.0405$ & $0.084 \pm 0.2141$ & BDL & $19.73 \pm 0.406$ \\
Karara white (C) & $21.81 \pm 0.517$ & BDL & $0.053 \pm 0.1222$ & 0.661 \\
Dinocite (D) & $17.25 \pm 0.208$ & $0.099 \pm 0.0488$ & $0.262 \pm 0.4455$ & $0.363 \pm 0.9837$ & $5.842 \pm 0.6227$ \\
Chocolate-1 (E) & $17.47 \pm 0.688$ & $0.017 \pm 0.0441$ & $0.649 \pm 0.5863$ & BDL & $25.20 \pm 1.000$ \\
Chocolate-2 (F) & $18.72 \pm 0.190$ & $0.064 \pm 0.0193$ & BDL & BDL & $28.09 \pm 0.304$ \\
Botiseena (G) & $18.96 \pm 0.592$ & $0.085 \pm 0.0240$ & BDL & BDL & $12.66 \pm 0.536$ \\
Afghani (H) & $22.01 \pm 0.810$ & $0.062 \pm 0.0300$ & BDL & $1.687 \pm 1.2341$ & $13.41 \pm 0.535$ \\
Silver pun (I) & $6.908 \pm 0.1509$ & BDL & $0.042 \pm 0.3049$ & $12.09 \pm 1.371$ & $15.97 \pm 0.336$ \\
\hline \multicolumn{1}{c}{ Sample ID } & Mg & Na & Ni & Pb & Zn \\
\cline { 2 - 6 } & & & & & \\
\hline China verona (A) & BDL & $10.90 \pm 0.854$ & $6.792 \pm 0.5261$ & $6.792 \pm 0.5261$ & BDL \\
Ziarat white (B) & BDL & $11.91 \pm 0.435$ & $5.449 \pm 0.0410$ & $0.606 \pm 1.2192$ & BDL \\
Karara white (C) & BDL & $9.989 \pm 0.4253$ & $7.677 \pm 0.2616$ & $1.800 \pm 0.3829$ & BDL \\
Dinocite (D) & $4.685 \pm 0.1402$ & $1.624 \pm 0.5397$ & $3.240 \pm 0.1757$ & $3.814 \pm 0.1849$ & BDL \\
Chocolate-1 (E) & $0.228 \pm 0.0615$ & $14.53 \pm 0.364$ & $6.601 \pm 0.3813$ & $0.937 \pm 0.9511$ & BDL \\
Chocolate-2 (F) & BDL & $47.32 \pm 1.272$ & $4.777 \pm 0.4565$ & $0.495 \pm 0.6672$ & BDL \\
Botiseena (G) & BDL & $5.519 \pm 0.7429$ & $4.046 \pm 0.3627$ & $1.199 \pm 0.3001$ & BDL \\
Afghani (H) & $0.025 \pm 0.0448$ & $5.070 \pm 0.8747$ & $3.298 \pm 0.1341$ & $3.976 \pm 0.1925$ & BDL \\
Silver pun (I) & $13.16 \pm 0.191$ & $13.30 \pm 0.664$ & $8.573 \pm 0.6558$ & $1.826 \pm 0.5146$ & $0.003 \pm 0.0285$ \\
\hline
\end{tabular}

\section{Transesterification}

Waste cooking oil (WCO) is a waste product produced in restaurants and domestically and is usually dumped. It destroys the sewerage system as well as cause a serious threat for the environment. The conversion of WCO oil into useful products such as biodiesel is a very significant approach. It can reduce the burden on fossil fuels and also keep the environment
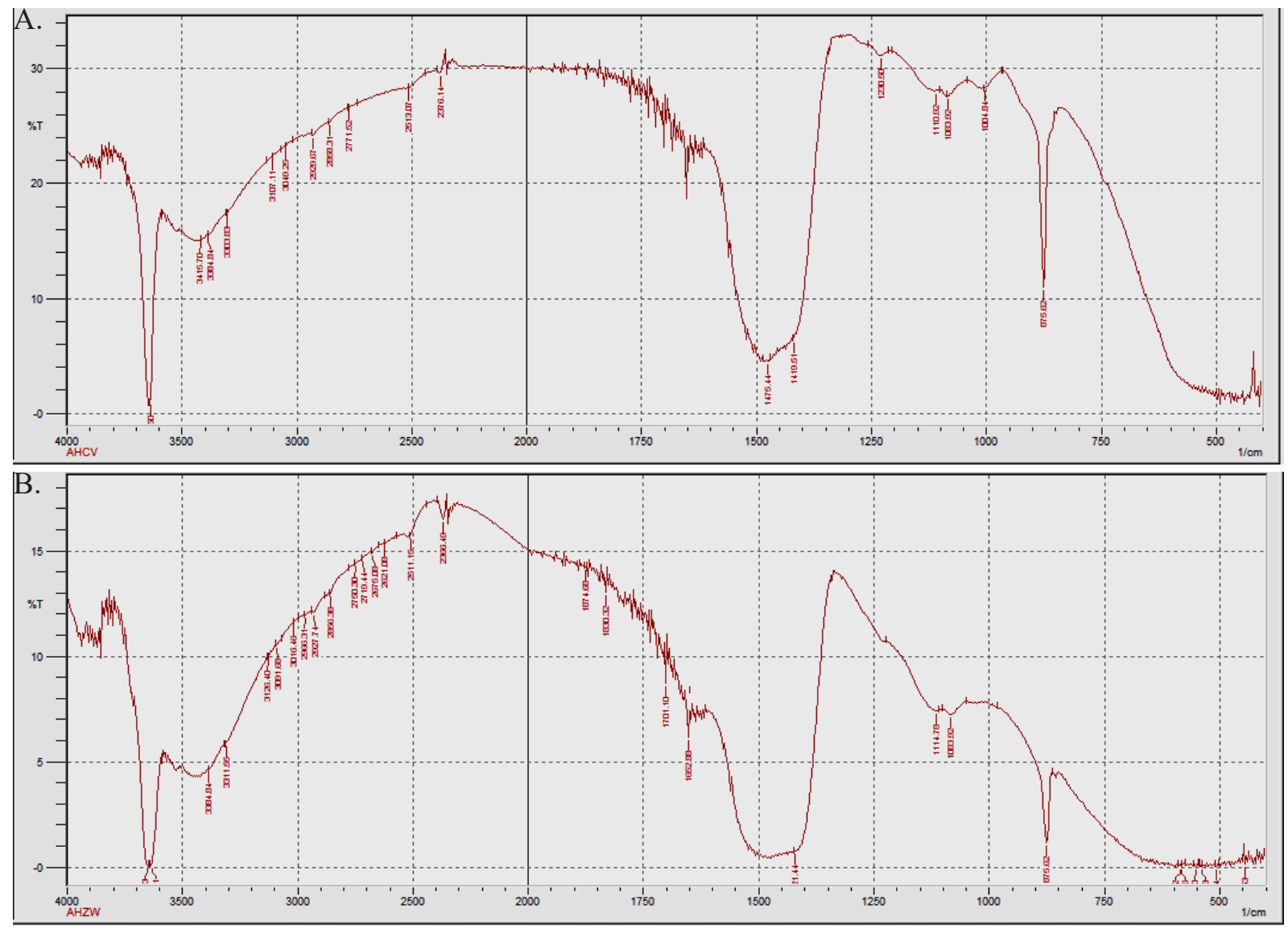

To be continued 
Figure 6. Continuation
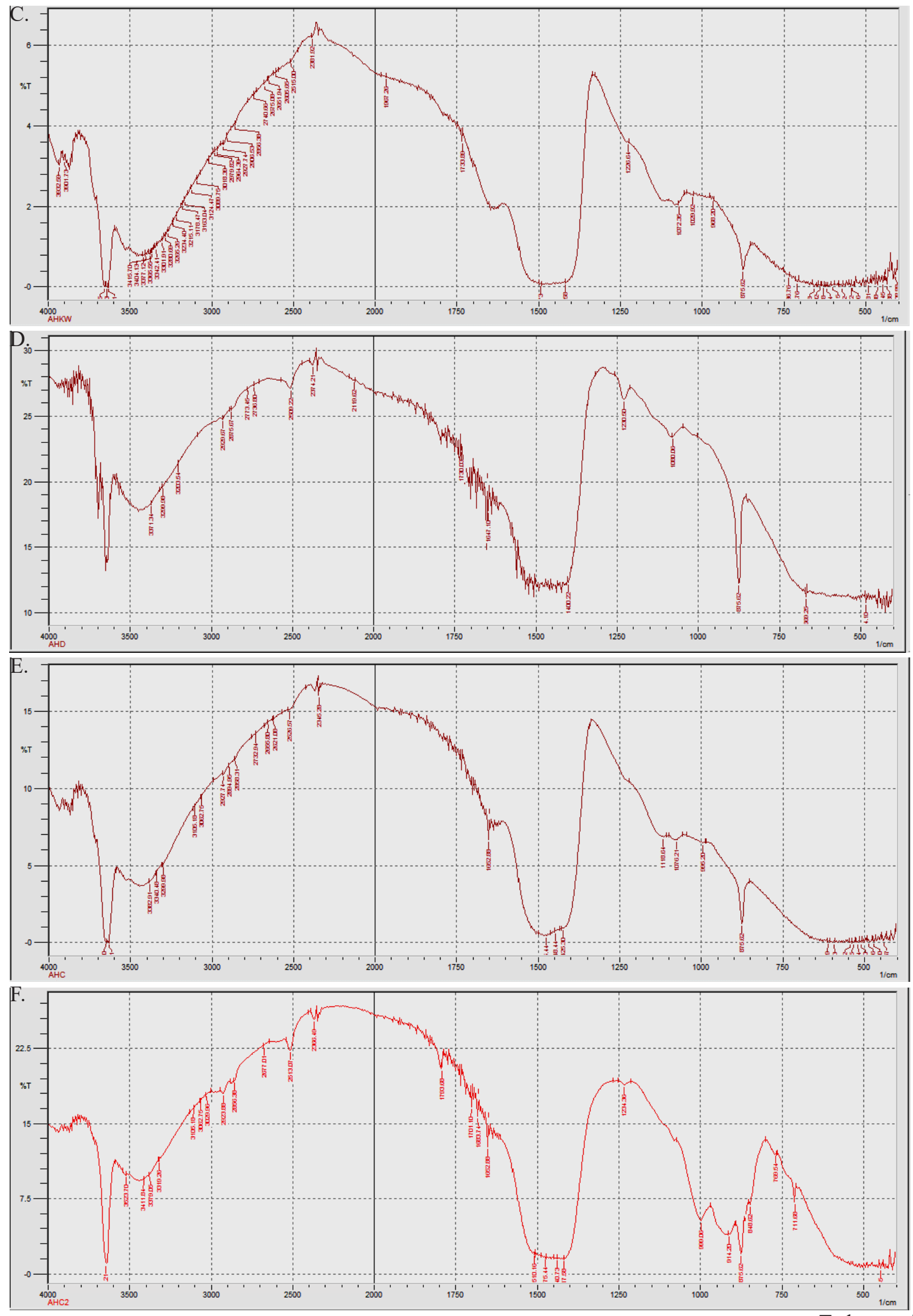

To be continued 
Figure 6. Continuation
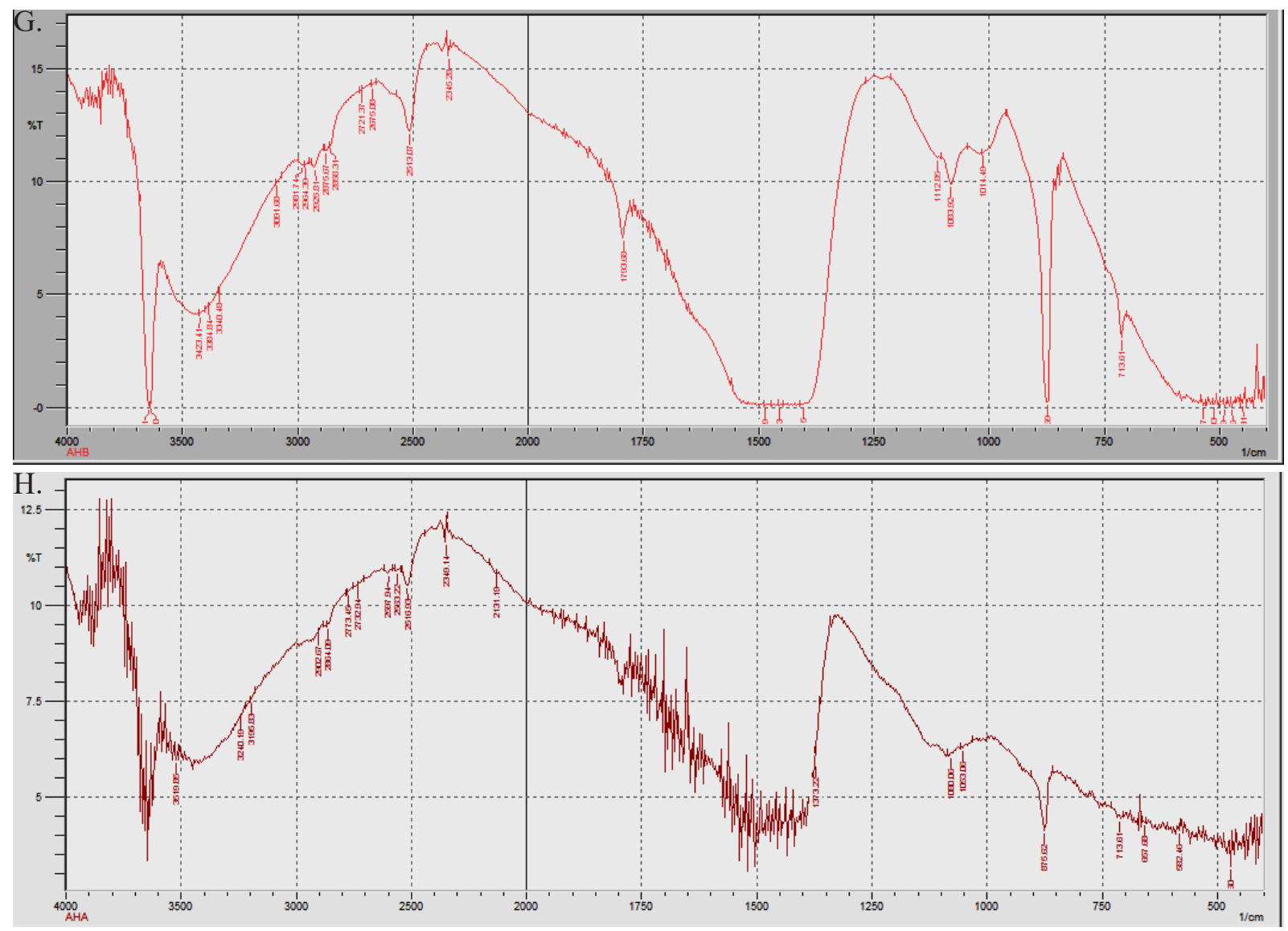

Figure 6. FT-IR spectrum of calcined China Verona marble (A), Ziarat white marble (B), Karara white marble (C), Dinocite marble (D), Chocolate-1 marble (E), Chocolate-2 marble (F), Botiseena marble (G) and Afghani marble (H).
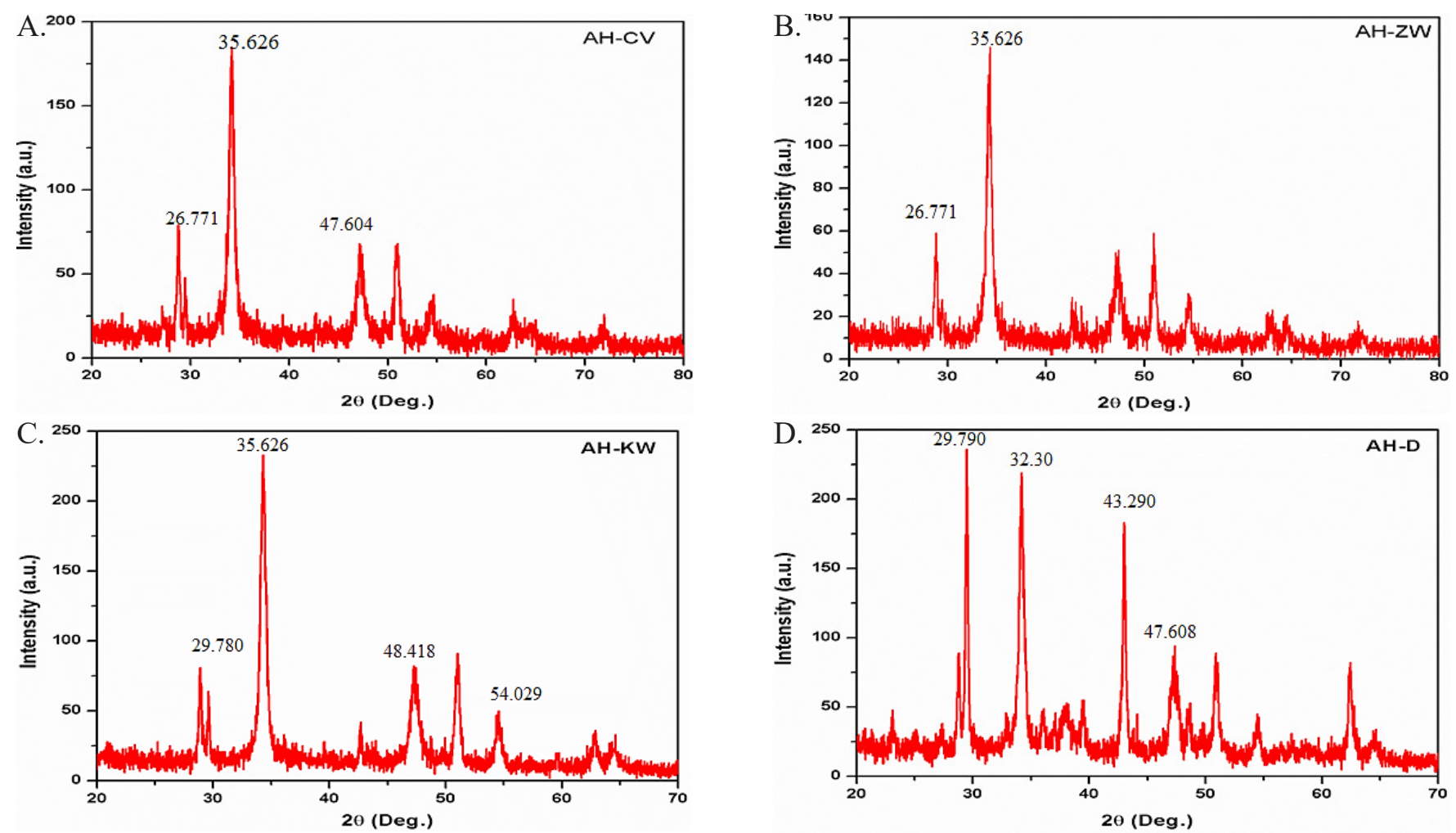

To be continued 
Figure 7. Continuation
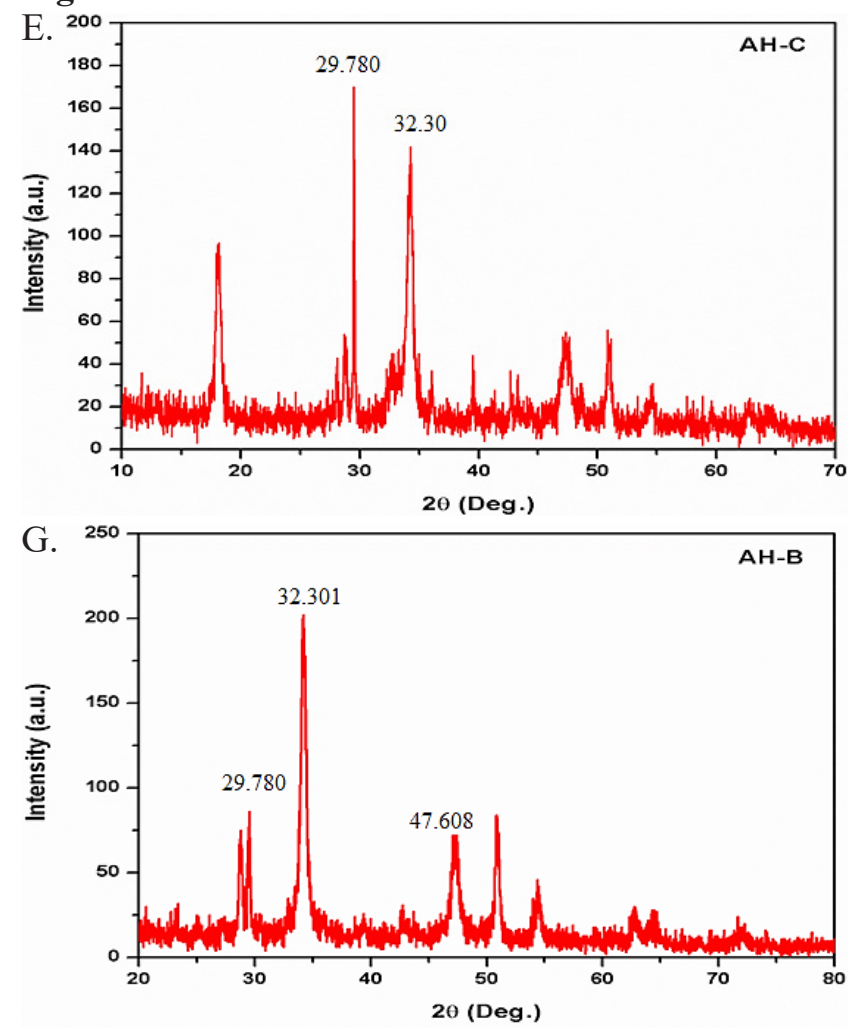
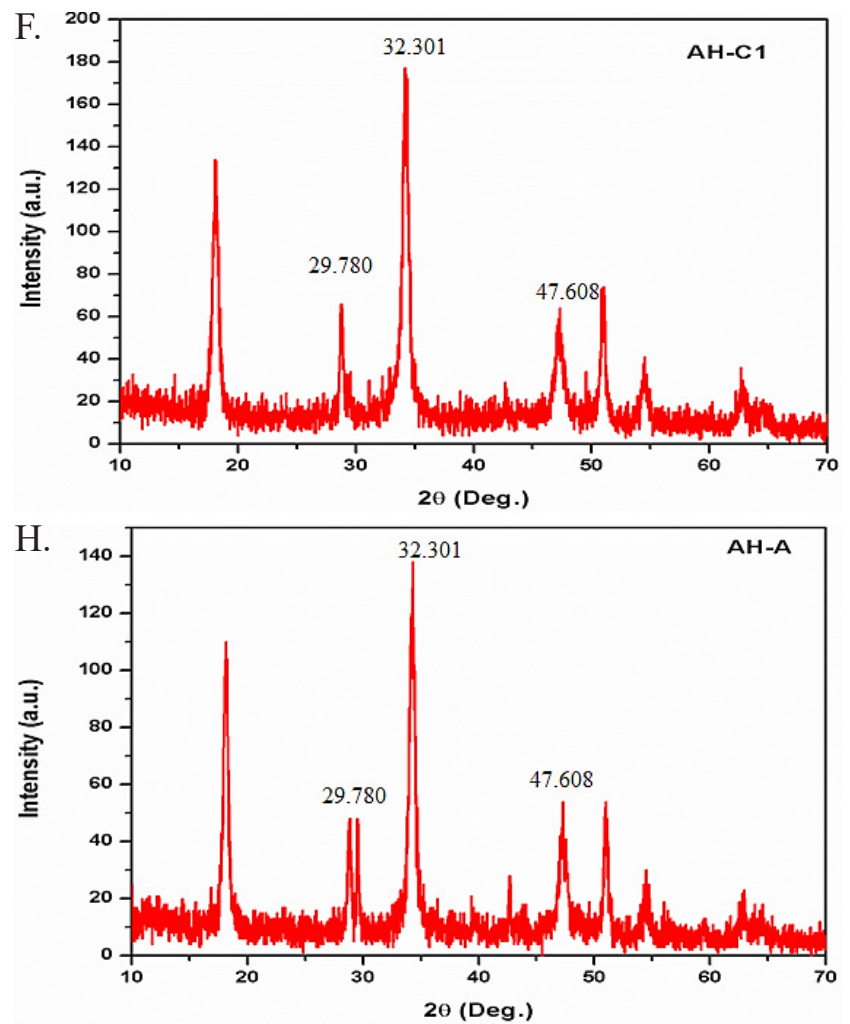

Figure 7. XRD pattern of calcined China Verona marble (A), Ziarat white marble (B), Karara white marble (C), Dinocite marble (D), Chocolate-1 marble (E), Chocolate-2 marble (F), Botiseena marble (G) and Afghani marble (H).

clean. WCO oil has been converted into biodiesel by a transesterification reaction. In the transesterification reaction, oil is converted into a small chain alkyl ester, i.e., biodiesel fatty acid methyl esters (FAME) or fatty acid ethyl esters (FAEE). Transesterification is a catalyst-dependent reaction. The catalyst plays a significant role in the transesterification reaction. In this research work, WCO oil has been converted into fatty acid methyl esters (FAME) using nine types of heterogeneous catalysts (A to I). All the catalysts were obtained from waste marble via calcination. The transesterification reactions with methanol in the presence of heterogeneous catalysts were carried under five different conditions, namely room temperature, conventional heating, solar ordinary irradiation, solar concentrated reflected irradiation and solar concentrated refracted irradiation. In each condition, transesterification reactions were carried out using nine types of catalysts separately. Each reaction was conducted for 1-5 minutes with continuous stirring to optimize the maximum \% yield. After each minute the $\%$ yield was calculated and it was observed that the maximum yield of biodiesel is produced after five minutes (Table 4). The transesterification reactions of WCO with methanol at room temperature were carried out in ordinary shadow. Here no source of energy such as direct sun rays or conventional heating was provided. It was found that all the catalysts gave significant $\%$ yield of biodiesel at room temperature except (I), which remained inactive. The same reactions were also carried out by conventional heating. Here the energy was provided in the form of heat using a hot plate. The same reactions were also carried out under ordinary solar irradiations. Here the solar light provided the heat for the reaction. It was found that the $\%$ yield of biodiesel (FAME) increased under ordinary solar irradiation as compared to room temperature.

The nine reaction flasks containing $\mathrm{WCO}$, methanol and different heterogeneous catalyst were kept under solar concentrated reflected irradiation. The solar radiation was reflected and concentrated by a satellite dish coated with aluminum foil. The reflected radiation was focused on the reaction flask. The reflected radiation was highly energetic, which enhanced the $\%$ yield of biodiesel significantly. Another series of reactions was conducted under solar concentrated refracted radiation for 1-5 minutes with continuous stirring. Here solar radiation was refracted by using a Fresnel lens $(30 \times 30 \mathrm{~cm})$. The refracted solar radiation was focused on the reaction flasks. The refracted radiation was highly energetic and increased the $\%$ yield of biodiesel to a larger extent. Finally, the $\%$ yield of biodiesel was compared with respect to the catalysts. In all conditions, it was found that the $\%$ yield ranged from 80 to $96 \%$ except at room temperature, where most of the catalysts gave a \% yield below $80 \%$ 
(Table 4). The \% yield for transesterification reactions conducted under solar irradiation were also compared with those conducted by conventional heating and solar irradiation was a more significant source of energy than conventional heating. The solar concentrated reflected and refracted irradiations increased the \% yield of biodiesel to a significant extent as compared to conventional heating and room temperature.

It was found that all the catalysts showed good catalytic activity except (I), which remained inactive in all conditions. The catalyst (I) did not contain significant $\mathrm{CaO}$ content. The most significant aspect of this research work is the use of waste raw material and free energy sources. The waste cooking oil as raw material is cheaper; however, it requires a processing cost to make it suitable for reaction. All catalysts were obtained from waste marble, which has almost no cost. However, it also has a processing cost when it is calcined at high temperature. Solar radiation was used as a renewable source of energy. Both of the solar systems (aluminum coated satellite dish and Fresnel lens) are able to intensify the solar radiation during cold weather.

\section{Mechanism of transesterification}

The transesterification reactions of triglycerides with methanol were catalyzed by basic heterogeneous catalysts containing $\mathrm{CaO}$ as basic catalyst. $\mathrm{CaO}$ can generate methoxide ion attached to the catalyst surface. Methoxide ion attacks the carbonyl carbon of the triglyceride to form a tetrahedral intermediate. In the second step, the tetrahedral intermediate rearranges to produce the diglyceride anion and a fatty acid methyl ester. The diglyceride anion abstracts a proton from the catalyst surface to form a diglyceride and regenerate the active site of the catalyst (Figure 8). The same steps repeated thrice produce three moles of fatty acid methyl ester and one mole of glycerol from one mole of triglyceride, consuming three moles of methanol (Kesic et al., 2016).

\section{Characterization of biodiesel}

The biodiesel produced was characterized by ASTM standards, TLC examination and GC analysis. It was found that all the parameters were within the limits of ASTM standards (Table 5). It has been found that the viscosity of WCO is very high and it is not suitable as a fuel, while biodiesel (FAME) has lower viscosity and is suitable to be used as a fuel. Since biodiesel (FAME) is less polar than oil, biodiesel runs faster on the stationary phase of silica gel with the solvent system of hexane: toluene: chloroform. The spots of biodiesel and oil were visualized with anhydrous iodine crystals. It was observed that iodine crystals are the best visualizing agent. The $R_{f}$ values of oil and FAME were found to be 0.53 and 0.83 , respectively. The $\%$ conversion of WCO to biodiesel was calculated from TLC examination (Table 4). The GC chromatogram of WCO showed one dominant peak at retention time 44.013 , while that of FAME showed three dominant

Table 4. Kinetics of yield (\%) of FAME produced in five different conditions*.

\begin{tabular}{|c|c|c|c|c|c|c|c|c|c|c|}
\hline \multirow{2}{*}{ Catalysts } & & \multicolumn{9}{|c|}{ Yield (\%) of FAME } \\
\hline & & $\mathbf{A}$ & B & $\mathbf{C}$ & D & $\mathbf{E}$ & $\mathbf{F}$ & G & $\mathbf{H}$ & $\mathbf{I}$ \\
\hline \multirow{5}{*}{$\begin{array}{c}\text { Room } \\
\text { temperature }\end{array}$} & $\mathrm{t}_{1}$ & 22.22 & 23.91 & 25.66 & 23.46 & 24.57 & 25.51 & 21.83 & 25.92 & - \\
\hline & $\mathrm{t}_{2}$ & 37.25 & 40.36 & 46.54 & 44.44 & 45.63 & 48.53 & 39.67 & 40.78 & - \\
\hline & $\mathrm{t}_{3}$ & 51.55 & 55.71 & 64.52 & 60.75 & 61.82 & 66.61 & 55.26 & 55.51 & - \\
\hline & $\mathrm{t}_{4}$ & 63.87 & 67.61 & 74.89 & 70.99 & 73.55 & 75.33 & 69.56 & 68.89 & - \\
\hline & $\mathrm{t}_{5}$ & 73.55 & 78.62 & 81.55 & 78.88 & 81.81 & 81.74 & 79.15 & 79.71 & 0 \\
\hline \multirow{5}{*}{$\begin{array}{c}\text { Conventional } \\
\text { heating }\end{array}$} & $\mathrm{t}_{1}$ & 22.98 & 24.62 & 27.11 & 25.78 & 25.66 & 25.45 & 24.93 & 26.44 & - \\
\hline & $\mathrm{t}_{2}$ & 39.99 & 45.55 & 50.85 & 47.88 & 46.99 & 49.55 & 46.16 & 49.69 & - \\
\hline & $\mathrm{t}_{3}$ & 57.65 & 60.65 & 69.74 & 65.65 & 64.54 & 67.78 & 63.32 & 66.76 & - \\
\hline & $\mathrm{t}_{4}$ & 68.87 & 71.88 & 84.91 & 81.71 & 78.21 & 74.71 & 73.43 & 84.18 & - \\
\hline & $\mathrm{t}_{5}$ & 76.67 & 80.77 & 96.30 & 92.00 & 88.74 & 84.78 & 84.62 & 95.65 & 0 \\
\hline \multirow{5}{*}{$\begin{array}{l}\text { Solar ordinary } \\
\text { heating }\end{array}$} & $t_{1}$ & 24.76 & 22.45 & 29.76 & 26.41 & 27.73 & 30.65 & 28.54 & 29.21 & - \\
\hline & $\mathrm{t}_{2}$ & 44.28 & 42.99 & 52.38 & 47.64 & 50.69 & 56.88 & 49.81 & 50.37 & - \\
\hline & $t_{3}$ & 61.54 & 58.51 & 68.99 & 60.34 & 67.49 & 74.21 & 64.39 & 67.54 & - \\
\hline & $\mathrm{t}_{4}$ & 73.93 & 69.79 & 81.89 & 71.65 & 78.19 & 84.94 & 78.42 & 81.63 & - \\
\hline & $\mathrm{t}_{5}$ & 83.44 & 79.03 & 92.61 & 80.25 & 85.94 & 91.31 & 89.68 & 89.34 & 0 \\
\hline \multirow{5}{*}{$\begin{array}{l}\text { Solar } \\
\text { reflection by } \\
\text { satellite dish }\end{array}$} & $t_{1}$ & 27.78 & 27.22 & 30.55 & 27.11 & 32.74 & 31.34 & 29.99 & 30.12 & - \\
\hline & $\mathrm{t}_{2}$ & 50.06 & 51.30 & 55.18 & 48.91 & 56.63 & 57.43 & 51.28 & 51.75 & - \\
\hline & $\mathrm{t}_{3}$ & 67.36 & 68.42 & 74.67 & 61.67 & 75.66 & 75.89 & 72.34 & 71.89 & - \\
\hline & $\mathrm{t}_{4}$ & 79.32 & 80.23 & 85.58 & 73.11 & 87.37 & 86.85 & 84.58 & 87.45 & - \\
\hline & $\mathrm{t}_{5}$ & 88.44 & 89.92 & 94.70 & 81.48 & 96.30 & 91.67 & 91.85 & 89.88 & 0 \\
\hline \multirow{5}{*}{$\begin{array}{l}\text { Solar } \\
\text { refraction by } \\
\text { Fresnel lens }\end{array}$} & $t_{1}$ & 28.33 & 31.35 & 31.39 & 28.99 & 31.98 & 30.98 & 30.79 & 31.45 & - \\
\hline & $t_{2}$ & 52.61 & 56.67 & 55.99 & 51.48 & 56.05 & 53.31 & 54.47 & 55.32 & - \\
\hline & $\mathrm{t}_{3}$ & 68.89 & 73.50 & 75.12 & 68.39 & 75.68 & 69.11 & 72.99 & 73.54 & - \\
\hline & $t_{4}$ & 80.10 & 85.90 & 86.47 & 79.91 & 86.45 & 81.49 & 84.89 & 75.67 & - \\
\hline & $\mathrm{t}_{5}$ & 87.44 & 94.83 & 94.76 & 89.45 & 94.87 & 92.66 & 95.80 & 96.10 & 0 \\
\hline
\end{tabular}




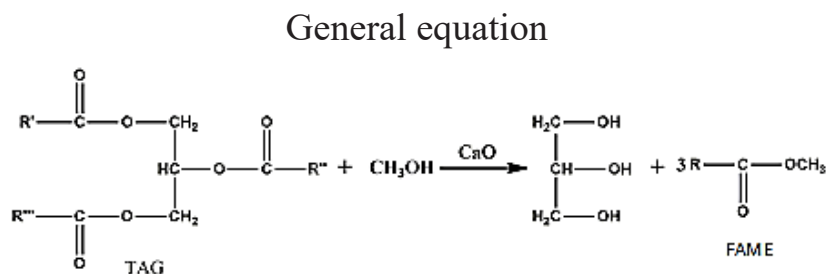

Mechanism
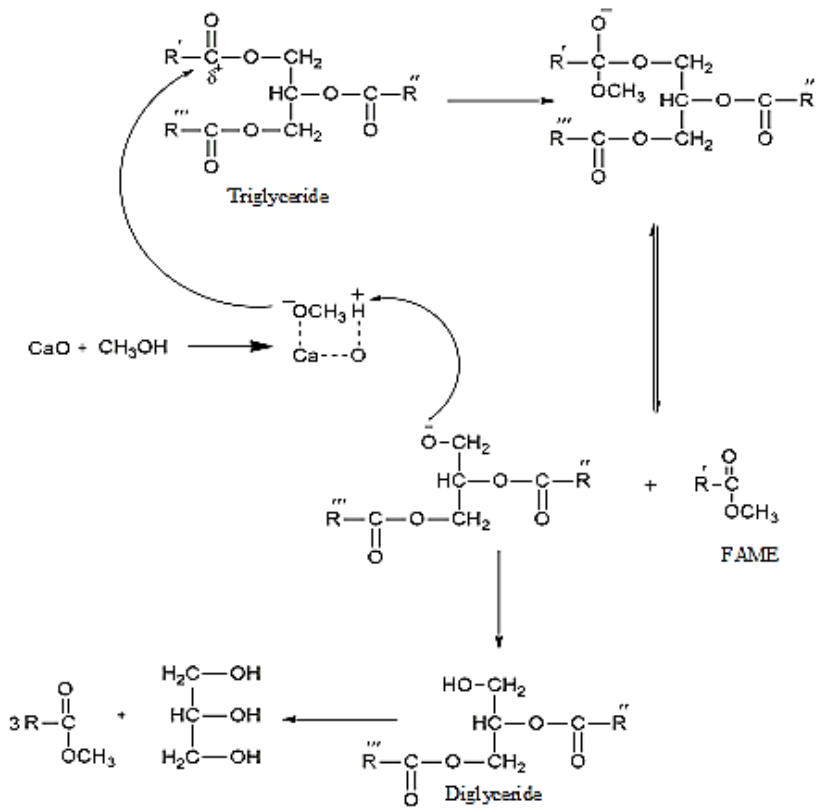

Figure 8. Mechanism of $\mathrm{CaO}$ catalyzed transesterification.

peaks at retention times $11.205,23.731$ and 33.754 (Figure 9A and 9B). However, in both chromatograms, different peaks appeared within the range of 10-60 min retention time.

\section{Significance of research}

This research work is based on the production of green, renewable and environmental friendly fuel (biodiesel) from waste cooking oil and methanol using waste marble as heterogeneous catalyst. Waste marble has no significant application. In this research work waste marble was used as a source of $\mathrm{CaO}$, which acts as an effective heterogeneous catalyst for the transesterification reaction. Waste marble is generated in huge amounts all over the world in marble factories and construction sites. Waste marble is easily available and cheap. However, there is some processing cost, particularly due to calcination at high temperature. It can replace expensive catalysts such as $\mathrm{CaO}-\mathrm{Al}_{2} \mathrm{O}_{3}, \mathrm{ZrO}_{2} / \mathrm{SO}_{4}^{-2}, \mathrm{TiO}_{2} / \mathrm{SO}_{4}{ }^{-2}, \mathrm{WO}_{3} /$ $\mathrm{ZrO}_{2}, \mathrm{Cs}-\mathrm{Na}_{2} \mathrm{ZrO}_{3}, \mathrm{CaO}-\mathrm{ZrO}_{2}, \mathrm{La}_{2} \mathrm{O}_{3}$ etc. and can be easily recovered for reuse. Biodiesel is the best alternative of fossil fuels. Consumption of fossil fuels increases the concentration of $\mathrm{CO}_{2}$ and $\mathrm{SO}_{x}$ in the environment, which is great threat to environment. Biodiesel is carbon neutral and can be used in current

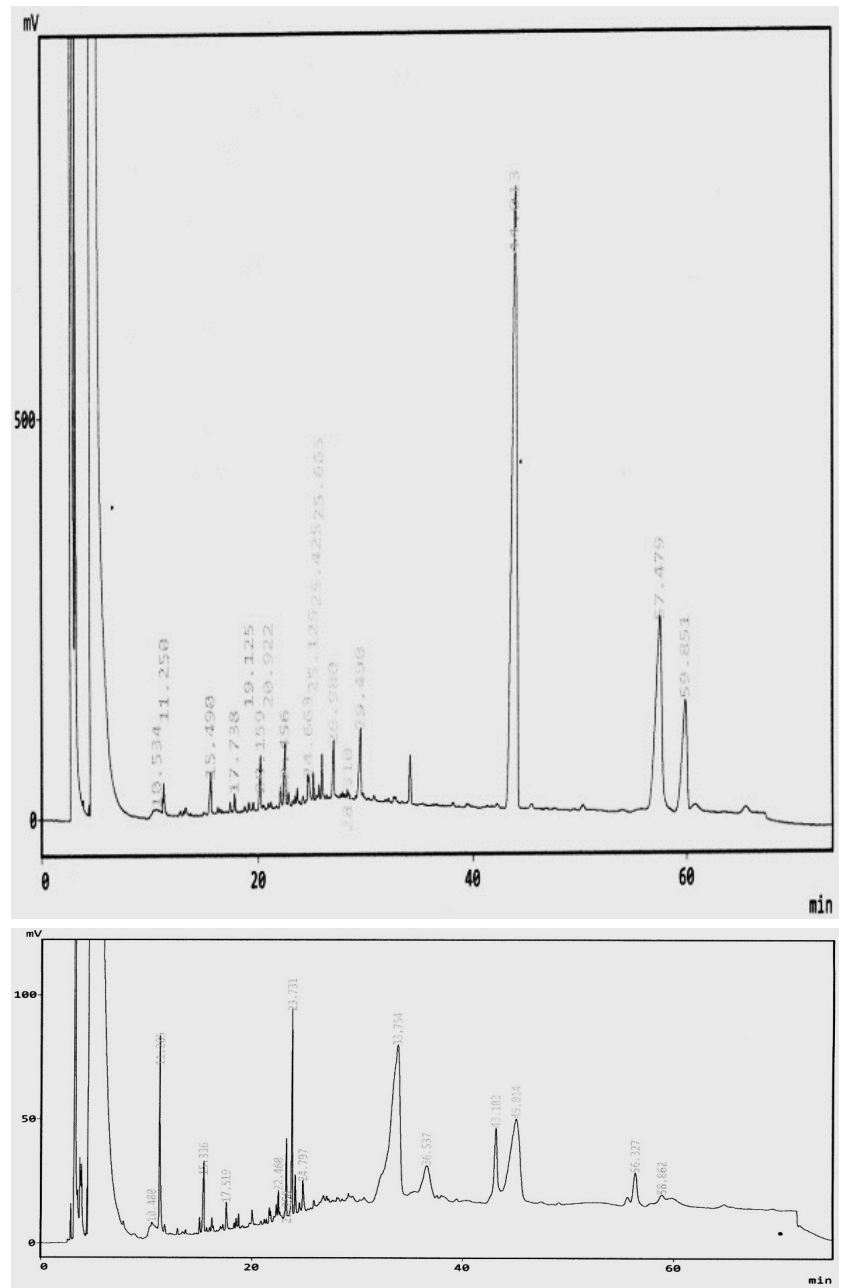

Figure 9. GC chromatograms of WCO (A) and FAME (B).

Table 5. Fuel properties of oil and FAME in comparison with ASTM standards.

\begin{tabular}{lccc}
\hline \multicolumn{1}{c}{ Parameters } & Oil & FAME & $\begin{array}{c}\text { ASTM standards } \\
\text { (Khan et al., 2016) }\end{array}$ \\
\hline Cloud point $\left({ }^{\circ} \mathrm{C}\right)$ & 5 & 0 & -3 to 12 \\
Pour point $\left({ }^{\circ} \mathrm{C}\right)$ & -1 & -2 & -15 to 10 \\
Density $(\mathrm{g} / \mathrm{ml})$ & 0.87 & 0.85 & 0.86 to 0.90 \\
Kinematic viscosity $\left(\mathrm{mm}^{2} / \mathrm{s}\right)$ & 28.11 & 3.90 & $1.9-6.0$ \\
Acid value $(\mathrm{mg} \mathrm{KOH} / \mathrm{g}$ oil $)$ & 6.85 & 0.47 & 0.50 \\
\hline
\end{tabular}

diesel engines without any alteration. Cooking oil is obtained from plants; therefore it is necessary to grow more plants for this purpose. Thus, the $\mathrm{CO}_{2}$ emitted from combustion of biodiesel is consumed by plants in photosynthesis, releasing oxygen to the environment and keeping the environment clean and green. The most significant aspect of this research work is the use of solar radiations as a source of energy. Solar radiation is a renewable source of energy. In this work, the intensity of solar radiation has been increased by using sn aluminum-coated satellite dish and Fresnel lens. Both of these concentrated the solar radiation and focused it on a single point. The main drawback 
in biodiesel production is its cost because vegetable oil available in large amounts is usually edible, which increases the cost of biodiesel and is also competitive with food. Waste cooking oil is the best source for biodiesel production because it is produced in large amounts all over the world and has no significant cost, although it requires the processing cost. Biodiesel produced through this research work will be of low cost when produced on a commercial scale.

\section{CONCLUSIONS}

The waste cooking oil produced in restaurants and domestically has no significant application and is a great threat to environment. Similarly, the wastes of marble are usually used as landfill, which is not a significant application. In this research work, both waste cooking oil and waste marble were utilized in the synthesis of a significant product, i.e., biodiesel. Waste cooking oil was used as raw material, while waste marble was used as heterogeneous catalyst. The waste marble mainly consists of calcium carbonate, which on calcination converted into calcium oxide. Different tests such as basicity test, gravimetric analysis and qualitative analysis were performed for calcined marble. It was concluded that calcium oxide produced by calcination of waste marble was strongly basic oxide. From different techniques such as FAAS and FT-IR performed on calcined marble, it was concluded that it can act as an effective heterogeneous catalyst in transesterification. It can be recovered easily and can be reused. Transesterification reactions were carried out under five different conditions. In all conditions, it was found that the catalysts prepared from waste marble gave high yields of biodiesel. Furthermore, it was observed that solar radiation can replace a conventional heating source as the yield of biodiesel obtained under solar conditions is much better than with conventional heating. It was observed that concentrated reflected and concentrated refracted solar radiations are better sources of energy for biodiesel production. Solar radiation is a renewable source of energy and it can reduce the cost of biodiesel. The use of an aluminum-coated satellite dish and a Fresnel lens is a new approach. The aluminum-coated satellite dish and Fresnel lens concentrate the solar radiation and hence increase its intensity, which is also effective in cold weather. This research work will play a significant role to overcome the current challenges of environmental pollution, global warming, energy crisis and biodiversity.

\section{ACKNOWLEDGMENT}

The authors are thankful to all those researchers whose references have been used to support this research article.

\section{REFERENCES}

Azcan, N., Danisman, A. Microwave assisted transesterification of rapeseed oil. Fuel, 87, 1781-1788 (2008). https://doi.org/10.1016/j. fuel.2007.12.004

Balakrishnan, K., Olutoye, M. A., Hameed, B. H. Synthesis of methyl esters from waste cooking oil using construction waste material as solid base catalyst. Bioresource Technology, 128, 788-791 (2013). https://doi.org/10.1016/j. biortech.2012.10.023

Bennett, J. A., Wilson, K., Lee, A. F. Catalytic applications of waste derived materials. J. Mater. Chem. A. 4, 3617-3637 (2016). https://doi. org/10.1039/C5TA09613H

Bharathiraja, B., Sutha, M., Sowndarya, K., Chandran, M., Yuvaraj, D., Kumar, R. P. Calcium oxide nanoparticles as an effective filtration aid for purification of vehicle gas exhaust. Advances in Internal Combustion Engine Research, 181-191 (2018). https://doi.org/10.1007/978981-10-7575-9_9

Charpe, T. W., Rathod, V. K. Biodiesel production using waste frying oil. Waste Management, 31, 85-90 (2011). https://doi.org/10.1016/j. wasman.2010.09.003

Dude, V. G., Grant, G. E. Biodiesel from waste cooking oil via direct sonication. Applied Energy, 109, 135-144 (2013). https://doi.org/10.1016/j. apenergy.2013.04.002

Farooq, M., Ramli, A. Biodiesel production from low FFA waste cooking oil using heterogeneous catalyst derived from chicken bones. Renewable Energy, 76, 362-368 (2015). https://doi.org/10.1016/j. renene. 2014.11 .042

Ilgen, O. Transesterification of canola oil using marble dust as a heterogeneous catalyst. Energy Sources, Part A, 34, 1688-1694 (2012). https://doi.org/10.10 $80 / 15567036.2010 .483457$

Itodo, A. U., Nnamonu, L. A., Ikape, V. O. Calcination analysis, characterization and dyestuff adsorption potential of Nigerian limestones. American Journal of Chemistry and Applications, 4, 6-20 (2017).

Kesic, Z., Lukic, I., Zdujic, M., Mojovic, L., Skala, D. Calcium oxide based catalysts for biodiesel production:Areview. Chemical Industry \& Chemical Engineering Quarterly, 22, 391-408 (2016). https:// doi.org/10.2298/CICEQ160203010K

Khan, A. M., Ameen, M., Fatima, N. Production of green and renewable biodiesel from marine brown alga Sargassum tenerrimum. Indian Journal of Geo Marine Science, 46, 815-824 (2017).

Khan, A. M., Fatima, N. Biodiesel synthesis via metal oxides and metal chlorides catalysis from marine alga Melanothamnus afaqhusainii. Chinese Journal of Chemical Engineering, 24, 388-393 (2016). https://doi.org/10.1016/j.cjche.2015.12.015 
Khan, A. M., Fatima, N. Synthesis of biodiesel from the oily content of marine green alga Ulva fasciata. J. Chem. Soc. Pak., 37, 1040-1046 (2015).

Khan, A. M., Fatima, N., Hussain, M. S., Yasmeen, $\mathrm{K}$. Biodiesel production from green seaweed Ulva fasciata catalyzed by novel waste catalysts from Pakistan steel industry. Chinese Journal of Chemical Engineering, 24, 1080-1086 (2016). https://doi.org/10.1016/j.cjche.2016.01.009

Khan, A. M., Hussain, M. S. Conversion of wastes to bioelectricity, bioethanol and fertilizer. Water Environment Research, 89, 676-686 (2017). https:// doi.org/10.2175/106143017X14839994522588

Kumar, D., Singh, B., Banerjee, A., Chatterjee, S. Cement wastes as transesterification catalysts for the production of biodiesel from Karanja oil. Journal of Cleaner Production, 1-23 (2018). https:// doi.org/10.1016/j.jclepro.2018.02.122

Mahesh, S. E., Ramanathan, A., Begum, K. M. M. S., Narayanan, A. Biodiesel production from waste cooking oil using $\mathrm{KBr}$ impregnated $\mathrm{CaO}$ as catalyst. Energy Conversion and Management, 91, 442-450 (2015). https://doi.org/10.1016/j. enconman.2014.12.031

Maneerung, T., Kawi, S., Dai, Y., Wang, C.H. Sustainable biodiesel production via transesterification of waste cooking oil by using $\mathrm{CaO}$ catalysts prepared from chicken manure. Energy Conversion and Management, 123, 487-497 (2016). https://doi.org/10.1016/j. enconman.2016.06.071

Mazaheri, H., Ong, H. C., Masjuki, H. H., Amini, Z., Harrison, M. D., Wang, C., Kusumo, F., Alw, A. Rice bran oil based biodiesel production using calcium oxide catalyst derived from Chicoreus brunneus shell. Energy, 10-19 (2017). https://doi. org/10.1016/j.energy.2017.11.073

Nisar, J., Razaq, R., Farooq, M., Iqbal, M., Khan, R. A., Sayed, M., Shah, A., Rahman, I. Enhanced biodiesel production from Jatropha oil using calcined waste animal bones as catalyst. Renewable Energy, 101, 111-119 (2017). https://doi.org/10.1016/j. renene.2016.08.048

Olutoye, M. A. Transesterification of crude Jatroph acurcaslinnaeus oil catalyzed by waste marble derived solid catalyst. Nigerian Journal of Technology, 34, 119-126 (2015). https://doi. org/10.4314/njt.v34i1.15

Pukale, D. D., Maddikeri, G. L., Gogate, P. R., Pandit, A. B., Pratap, A. P. Ultrasound assisted transesterification of waste cooking oil using heterogeneous solid catalyst. Ultrasonics Sonochemistry, 22, 278-286 (2015). https://doi. org/10.1016/j.ultsonch.2014.05.020

Tan, Y. H., Abdullah, M. O., Nolasco-Hipolito, C., Taufiq-Yap, Y. H. Waste ostrich- and chickeneggshells as heterogeneous base catalyst for biodiesel production from used cooking oil: Catalyst characterization and biodiesel yield performance. Applied Energy, 160, 58-70 (2015). https://doi.org/10.1016/j.apenergy.2015.09.023

Talebian-Kiakalaieh, A., Amin, N. A. S., Mazaheri, H. A review on novel processes of biodiesel production from waste cooking oil. Applied Energy, 104, 683-710 (2013). https://doi.org/10.1016/j. apenergy.2012.11.061

Vahid, B. R., Haghighi, M. Biodiesel production from sunflower oil over $\mathrm{MgO} / \mathrm{MgAl}_{2} \mathrm{O}_{4}$ nano catalyst: Effect of fuel type on catalyst nanostructure and performance. Energy Conversion and Management, 134, 290-300 (2017). https://doi.org/10.1016/j. enconman.2016.12.048

Witoon, T. Characterization of calcium oxide derived from waste eggshell and its application as $\mathrm{CO}_{2}$ sorbent. Ceramics International, 37, 3291-3298 (2011). https://doi.org/10.1016/j. ceramint.2011.05.125 